噴門側胃切除術後の食道内逆流および胃運動・胃排出よりみた 再建術式の実験的検討

\author{
順天堂大学第 1 外科学教室（主任：城所 仂教授） \\ 巾宣宣
}

\title{
AN EXPERIMENTAL STUDY OF OPERATIVE PROCEDURE BASED ON ESOPHAGEAL REFLUX AND GASTRO-DUODENAL MOTILITY FOLLOWING PROXIMAL GASTRECTOMY
}

Takanori HABA

The first Department of Surgery, Juntendo University, School of Medicine.

(Director : Prof, Tsutomu Kidokoro)

本研究の目的は，噴門側胃切除術後の食道内逆流が予防され，胃排出の良好な術式を検討すること にある，対象は成犬48頭を用い，方法は，食道胃内・内圧，胃運動，食道炎を指標とし，(1)食道胃吻 合法一端々吻合 (E-E) および端側吻合胃泡形成 (E-S), (2)胃切除範团一 $1 / 2$ または $1 / 3$ 切除, (3)幽門形 成術 (PP) 付加の有無, (4)選択的近位迷走神経切離術 (SPV) 付加の有無により術式の検討を行った. その結果，E-S 群では切除範囲㘧よび付加手術の有無に無関係に E-E 群に比べ食道内逆流は少なく食 道炎も軽度であった, 1/3切除の場合は SPV を付加すれば PP 付加は必ずしす必要でないが, $1 / 2$ 切除 の場合は，SPV 付加の有無に関係なくPP 付加が適当であることが分った.

索引用語：噴門側胃切除術，食道胃前壁端側吻合胃泡形成術，噴門側胃切除後残胃十二指腸運動，逆流性食道炎

\section{I. 緒 言}

噴門側胃切除術 (以下噴切術)は, 1898年 Mikulicz ${ }^{1)}$ が噴門癌にはじめて試み, Voelcker ${ }^{2} に よ り$ 最初に成 功例として報告されており，本邦では，1952年久留3が 高位胃潰瘍に施行した 4 例の噴切術例を報告してい る. 噴切術後は, (1)噴門部括約機構の久落, (2)残胃の 胃内貯蔵能の低下，(3)残胃運動機能の低下，などによ り, 逆流性食道炎（以下食道炎）の発生頻度が高い. 術後の食道炎の予防法として, 食道・胃吻合法の工夫, 空腸挿入術などによる逆流路の延長化，選択的近位迷 走神経切離術 (selective proximal vagotomy: SPV) や幽門形成術 (pyloroplasty: PP) などが試みられて きているが4) ，煩雑な術式が多く，普及性にとぼしい のが現況である。本研究の目的は，イヌを用いて噴切 後の胃内容の食道内逆流を, 食道胃内 $\mathrm{pH} \cdot$ 内圧, 残胃 運動，および食道の病理組織学的所見を指標として,

$<1985$ 年12月11日受理 >別刷請求先：巾 尊宣

干113 文京区本郷 2-1-1 順天堂大学医学部第 1 外科
食道胃吻合法, 胃切除範囲, PP あるいは SPV の有無 で検討し，簡便でかつ確実に逆流が予防でき，胃内容 の排出もより生理的な術式を確立することにある。

\section{II. 研究対象ならびに研究方法}

1. 研究対象

研究対象は, 体重8 16kg の雌雄雑種成犬 48 頭であ る.

2. 研究方法

1）実験群

（1）実験対象作成法

(1) 噴切術：イヌは24時間絶食後, Pentobarbital 25 $\mathrm{mg} / \mathrm{kg}$ 静脈内投与で床酔された. 手術はすべて無菌的 に行われ，胃切除時拉よび force transducer 縫着時 は，胃の收縮を予防する目的で atropine sulfate 0.05 $\mathrm{mg} / \mathrm{kg}$ が皮下注された.イヌは上腹部正中切開で開腹 後, 胃の支配血管を指標として, 噴門側 $1 / 3$ 胃切除術(以 下 $1 / 3$ 切除）噴門側 $1 / 2$ 胃切除術（以下 $1 / 2$ 切除）が行わ れた。肛門側切離線は $1 / 3$ 切除では小弯を左胃動脈第 3 枝の胃流入点とし，大弯を短胃動脈第 3 枝の胃流入点 
図 1 食道胃吻合法

$\mathrm{a}$ ：食道之残胃口側断端の大弯側を端々に吻合する ため胃泡はない. b : 食道を残胃口側断端の大弯側 先端より $4 \mathrm{~cm}$ 肛門側の前壁中央部に端側に吻合後, 口側に残された大弯側先端部までの部分を食道後壁 に固定し，人口的胃泡を形成する.

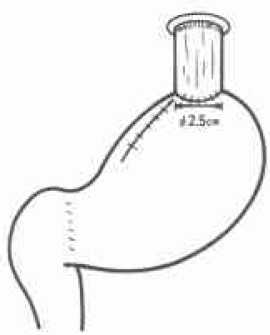

a 食道・周端々吻合術

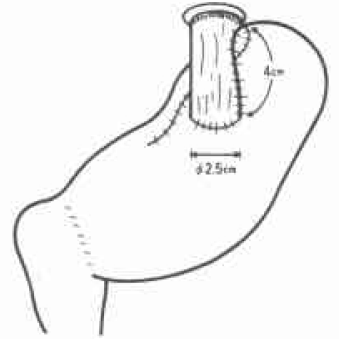

b 食道・胃端側吻合角泡形成術
とし，これらを結んだ線とした。また $1 / 2$ 切除では，小 弯を左胃動脈第 4 枝の胃流入点とし, 大弯を右胃大網 動脈最終枝の胃流入点とし,これらを結んだ線とした。 口側は，食道胃接合部（以下接合部）の口側約 $1 \mathrm{~cm} の$ 部で切離された。

\section{(2) 食道胃吻合術}

食道胃端々吻合術 (end-to-end anastomosis : E-E) は, 残胃口側断端大弯側で, 吻合口径が $2.5 \mathrm{~cm}$ となる 様に行われた（図 1 左）。食道胃端側吻合胃泡形成術 (end-to-side anastomosis : E-S) は，残胃口側断端を 2 層に閉鎖後, 大弯口側先端部より約 $4 \mathrm{~cm}$ 肛門側の前 壁中央部に，吻合口径 $2.5 \mathrm{~cm}$ となるように行われ，吻 合部より口側で大弯側先端部までの部分は食道後壁に 固定された. 吻合法は, 後壁が mattress 縫合, 前壁が Gambee一層縫合で行われた。

(3) 幽門形成術 (PP)

PPは，幽門輪より口側および肛門側各々 $1.5 \mathrm{~cm} の$ 前壁全層緃切開後, Gambee一層で横縫合を行ら Heineke-Mikulicz 型Weinberg変法により行われ た.

(4) 選択的近位迷走神経切離術 (SPV)

SPV は, 前後の Latarjet 神経を確認温存後, 幽門輪 より約 $5 \mathrm{~cm}$ 口側の胃枝をすべて血管とともに結禁切 離して行われた。この操作で注意を要する点は, 接合 部附近で横隔膜を損傷し，開胸しないことである。

(5) 全幹迷走神経切離術 (truncal vagotomy: TV)

TV は, 右側臥位で左第 8 肋間で開胸後, 食道下部で 迷走神経の前枝と後枝を約 $1.5 \mathrm{~cm}$ にわたり切除し, 行 われた。
（2）実験対象群

食道胃吻合法, 胃切除範囲, PP および SPV または TVの有無により, 実験群は次の17群に分類された.す なわち, (1)無処置正常犬 (以下対照群), (2) $1 / 3$ 切除端々 吻合 SPV・PP (+) 群, (3) $1 / 3$ 切除端々吻合 SPV •PP (一) 群, (4) $1 / 3$ 切除端々吻合 TV ・ PP (+) 群, (5)1/ 3 切除端々吻合 TV ・ PP (-) 群, (6) $1 / 3$ 切除端側吻合 $\mathrm{SPV} \cdot \mathrm{PP}(+)$ 群, (7) $1 / 3$ 切除端側吻合 SPV $\cdot \mathrm{PP}(-)$ 群, (8) $1 / 3$ 切除端側吻合 TV $\cdot P P(+)$ 群, (9) $1 / 3$ 切除 端側吻合 TV • PP (一) 群(10) $1 / 2$ 切除端々吻合 SPV • $\mathrm{PP}(+)$ 群, (11) $1 / 2$ 切除端々吻合 $\mathrm{SPV} \cdot \mathrm{PP}(-)$ 群, (12) $1 / 2$ 切除端々吻合 TV ・ PP (十) 群, (13) $1 / 2$ 切除端々 吻合 TV • PP (-) 群, (14) $1 / 2$ 切除端側吻合 SPV $\cdot$ PP (+) 群, (15) $1 / 2$ 切除端側吻合 SPV・PP (-) 群, (16) $1 /$ 2 切除端側吻合 TV - PP (+) 群, (17) $1 / 2$ 切除端側吻合 $\mathrm{TV} \cdot \mathrm{PP}$ (一) 群，の17群である. (1)群が12頭（他の 群を夷験する前に行われた）で，他の群は各群 3 頭で 検討された。

2）食道胃内圧測定

内环は Code ら ${ }^{8)}$ の方法に従い, 電気圧力計を用いる open tipped methordにより測定された.内压誘導管 は, 先端が閉鎖され径 $1.2 \mathrm{~mm}$ の側孔を 1 個有する外径 $1.9 \mathrm{~mm}$, 内径 $1.2 \mathrm{~mm}$ の polyethylene 管 2 本を接着し たものが使用され，生理食塩水 $0.5 \mathrm{ml} / \mathrm{min}$ を注入しな がら王測定を行ら inffusion 法が用いられた。測定は， 麻酔下にイヌを左側卧位とし，胃内に㨀入した誘導管 を, 速度 $3 \mathrm{~cm} / \mathrm{min}$ で徐々に引き抜き，静止圧を polygraph system (日本光電社製) を用い記録紙速度 $3 \mathrm{~cm} /$ min. で連続的に記録し行われた。

3）食道胃内 $\mathrm{pH}$ 測定

食道胃内 $\mathrm{pH}$ 測定は, 外径 $2.3 \mathrm{~mm}$ の微小ガラス電極 （富士化学計測社製 MODEL-ME501G）を使用し, pH meter (富士化学計測社製 MODEL-ES-05)にて行われ た. $\mathrm{pH}$ の測定は, イヌを麻酔直後に左側卧位とし, 内 視鏡直視下に口側食道より $3 \mathrm{~cm}$ 扣きに胃および十二 指腸まで行われ，同位置で最低 2 点の $\mathrm{pH}$ が測定され た。

4）Barium X 線検査による胃内容逆流および胃排 出の検討

Barium（以下 $\mathrm{Ba）} \mathrm{X}$ 線検査による胃内容逆流は, イヌを麻酔後, 経口的に胃管を挿入し，33\%硫酸 $\mathrm{Ba}$ $150 \mathrm{ml}$ 注入後, 胃管を拔去し, 直ちに背卧位水平位, 背 臥位頭部 $20^{\circ}$ 高位, 背臥位頭部 $20^{\circ}$ 低位と腹臥位で同 3 方向の計 6 方向の撮影が行われ，胃内容逆流の有無・ 
程度が観察された。また，胃内容排出は，意識下に Barium meal $20 \mathrm{gr} / \mathrm{kg}$ を与えた後，1時間ごとに撮影 が行われ，胃内容の完全排出まで観察された.

5）胃運動測定

胃運動は, 伊藤9)の方法に従い, 防水型 strain gauge force transducer (Star Medical 社製 Model F-12IS50）(以下FT）を用いて記録された，FT 縫着は，輪 状笳収縮を導出できる方向とし，全筋層を含むように 行われた。縫着部位は，非切除胃では，噴門部，胃体 部，胃角部，幽門部，幽門輪前 $2 \mathrm{~cm}$ ，幽門輪，十二指腸 球部, 十二指腸下行脚の 8 力所の前壁中央部に，また， 噴切術後は, 胃体部, 幽門部, 幽門輪, 十二指腸球部 の 4 力所とされた。導線は，側腹部で腹腔より出し， 皮下を通し背部の肩甲骨の間の皮膚小切開孔より取り 出した後, pinconnectorに接続された。記録は，術後 十分な回復期間を置いた後，意識下無拘束で連続観察 記録された。観察期間中, 食慨は1 日 1 回, 定刻に Dog food $20 \mathrm{gr} / \mathrm{kg}$ が与えられ，水は自由に与えられた。

6）食道炎の病理組穖学的検討

食道炎の有無・程度は，観察期間中は内視鏡的に観 察され，同時に直視下生検を併用し病理組織学的検討 が行われた。観察終了後イ邓は嗜殺され，残胃，食道， および吻合部の病理組織学的検討が行われた。

$$
\text { III. 成 }
$$

1. 食道胃内圧

1）対照犬の食道胃内圧

対照犬の内圧は，下部食道噴門括約筋 (以下 LES) に一致して内压上昇帯が認められた。昇圧部最高圧は, $18.1 \pm 9.5 \mathrm{cmH}_{2} \mathrm{O}$ であり，呼吸相変換点を通過後急激 に低下し, 胃内静止圧より低値となった。 LES 前後の 圧差は $4.7 \pm 2.3 \mathrm{cmH}_{2} \mathrm{O}$ であり, 昇圧帯の長さは $20.7 \pm 6.2 \mathrm{~mm}$ であった（図2）。

2）噴切術後の食道胃内圧

（1）食道胃端々吻合群 (E-E 群)

$\mathrm{E}-\mathrm{E}$ 群の接合部最高圧は $1.5 \pm 0.5 \mathrm{cmH}_{2} \mathrm{O}$ で E-S 群 に比べ有意に低值であった $(\mathrm{p}<0.01)$ 。また，接合部 前後の圧差は $1.7 \pm 0.8 \mathrm{~cm} \mathrm{H}_{2} \mathrm{O}$, 昇王帯の長さは14.5土 $3.1 \mathrm{~mm}$ といずれる E-S 群に比べ低值であったが有意 差は見られなかった（図2）。

（2）食道胃端側吻合胃泡形成群（E-S 群）

$\mathrm{E}-\mathrm{S}$ 群の接合部最高圧は, $4.2 \pm 0.7 \mathrm{cmH}_{2} \mathrm{O}$, 接合部 前後の圧差は, $2.3 \pm 1.1 \mathrm{cmH}_{2} \mathrm{O}$, 界圧帯の長さは $16.9 \pm 5.3 \mathrm{cmH}_{2} \mathrm{O}$ でいずれの值も対照犬の値に比べ 有意に低下していたが, E-E 群に比べ高值であった(図
図2 吻合法別食道胃接合部内压および波形 端側吻合で接合部最高圧は有意に高値となっている。

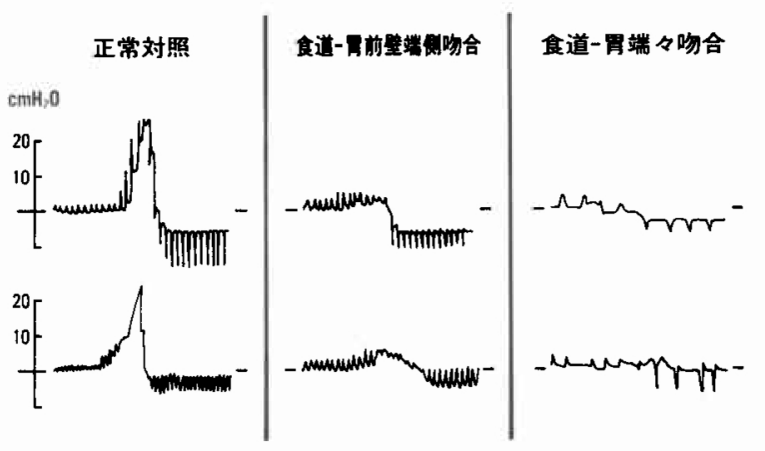

\begin{tabular}{|c|c|c|c|c|}
\hline & 頭数 & $\begin{array}{c}\text { 淁合部の長さ } \\
(\mathbf{m m})\end{array}$ & $\begin{array}{c}\text { 接合部漼高压 } \\
\left(\mathrm{cmHH}_{2} \mathrm{O}\right)\end{array}$ & $\begin{array}{c}\text { 接合部前後の圧美 } \\
\left(\mathrm{CmH}_{2} \mathrm{O}\right)\end{array}$ \\
\hline 正常対照 & 12 & $\begin{array}{r}20.7 \\
\pm 6.2\end{array}$ & $\begin{array}{c}18.1 \\
\pm 9.5 \\
\end{array}$ & $\begin{array}{l}4.7 \\
\pm 2.3\end{array}$ \\
\hline 端側吻合 & 24 & $\begin{array}{l}16.9 \\
\pm 5,3 \\
\end{array}$ & $\underbrace{4.2}_{ \pm 0.7} *$ & $\begin{array}{l}2.3 \\
\pm 1.1 \\
\end{array}$ \\
\hline 䡛々吻合 & 24 & $\begin{array}{c}14.5 \\
\pm 3.1\end{array}$ & $\underbrace{1.5}_{ \pm 0.5} *$ & $\begin{array}{l}1.7 \\
\pm 0.8\end{array}$ \\
\hline
\end{tabular}

2).

（3）切除範囲および付加手術の有無から見た食道胃 内圧変化.

$1 / 3$ 切除群 と $1 / 2$ 切除群では，接合部最高圧，接合部 前後の圧差, 昇圧帯の長さに有意差は認められなかっ た。 た付加手術（PP, SPV）の有無で検討しても， 接合部最高圧, 圧差, 昇圧帯の長さに有意差は認めら。 れなかった。

2. 食道胃内 $\mathrm{pH}$

1）対照犬の $\mathrm{pH}$

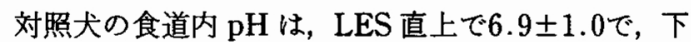
部食道, 中部食道己同様中性域で变化した。 しかし胃 内 $\mathrm{pH}$ は, LES 直下で2.1土1.50と LES を境に急激に 低下し，酸性城を示した。

2) 噴切術後の $\mathrm{pH}$

（1）食道胃吻合法と切除範囲

$1 / 3$ 切除 E-E 群の吻合部直上および下部食道 $\mathrm{pH}$ は，それ染れ $1.49 \pm 0.14 ， 2.80 \pm 0.72$ と対照群に比べ 有意 $(\mathrm{p}<0.01)$ 飞低く（図 $3 a$ a)，1/2切除 E-E 群子吻 合部直上 $(\mathrm{pH}=3.90 \pm 2.07)$ で, 対照群に比べ有意 $(\mathrm{p}<$ 0.05）に低下していた（図 3 b)。乙かし，E-S 群では $1 / 3$ 切除 E-S 群の吻合部直上 $\mathrm{pH}(\mathrm{pH}=4.96 \pm 0.65)$ が，対照群より有意 $(\mathrm{p}<0.05)$ に低いのみで，添対 照群と類似した $\mathrm{pH}$ 变化が見られ，切除範囲の大きさ 
図 3 切除範囲と吻合法，および，吻合法と $\mathrm{PP}$ 付加の有無，より見た食道胃内 $\mathrm{pH}$ 変 化
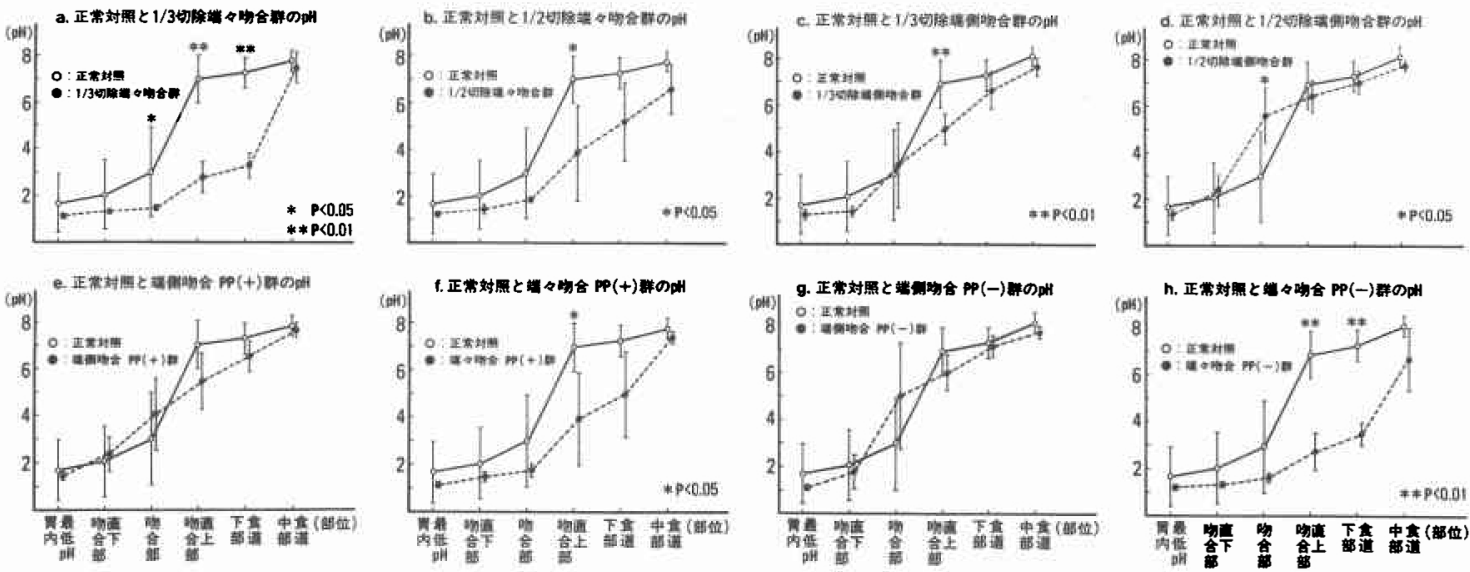

に無関係に E-S 群では E-E 群に比べ, 食道内 $\mathrm{pH}$ は高 值を示した（図 $3 \mathbf{c} \cdot \mathbf{d}$ ).

（2）食道胃吻合法と PP 付加の有無

E-E-群では PP 付加群 (以下 PP $(+)$ ) で吻合部直

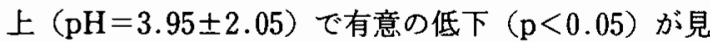
られ（図 $3 \mathbf{f}$ ), さらに PP 非付加群 (以下 $\mathrm{PP}(-)$ ) で吻合部直上 $(\mathrm{pH}=2.75 \pm 0.68)$, 下部食道 $(\mathrm{pH}=$ $3.50 \pm 0.51)$ 供に対照群に比べ有意 $(\mathrm{p}<0.01)$ に の低下が認められたが(図 $3 \mathbf{h}$ ), その程度は PP (+) で軽度であった，E-S 群では PP (十), PP (一) とも に，ほぼ対照群に近い $\mathrm{pH}$ 変化を示した（図 $3 \mathbf{e} \cdot \mathbf{g}$ ).

（3）食道胃吻合法と SPV 付加の有無

E-S 群では SPV 付加群 (以下 SPV 群) および SPV 非付加群 (以下 TV 群) ともに, 対照群と類似した pH 変化であったが, E-S・TV 群で吻合部直上 $\mathrm{pH}$ は5.7士 0.66 と有意に低かった（図 $4 \mathrm{c} \cdot \mathrm{d}$ ). E-E・TV 群では, 吻合部直上で $\mathrm{pH}=2.40 \pm 0.40$, 下部食道でる $\mathrm{pH}=$ $4.08 \pm 1.26$ であり，対照群に比べ有意 $(p<0.01)$ に低 値を示した（図 4 b). E-E・SPV 群では吻合部直上で $\mathrm{pH}=4.30 \pm 1.75$ と対照群に比へ，有意に低值（p< 0.05）であり，下部食道，中部食道も有意差はないも のの, 対照群より低い $\mathrm{pH}$ 値であった（図 4 a).

（4）切除範囲と PP 付加の有無

$1 / 3$ 切除 PP (+), 1/3切除 PP (-), 1/2切除 PP

図 4 吻合法と SPV 付加の有無, おょび，切除範囲と PP 付加の有無，より見た食道 胃内 $\mathrm{pH}$ 変化
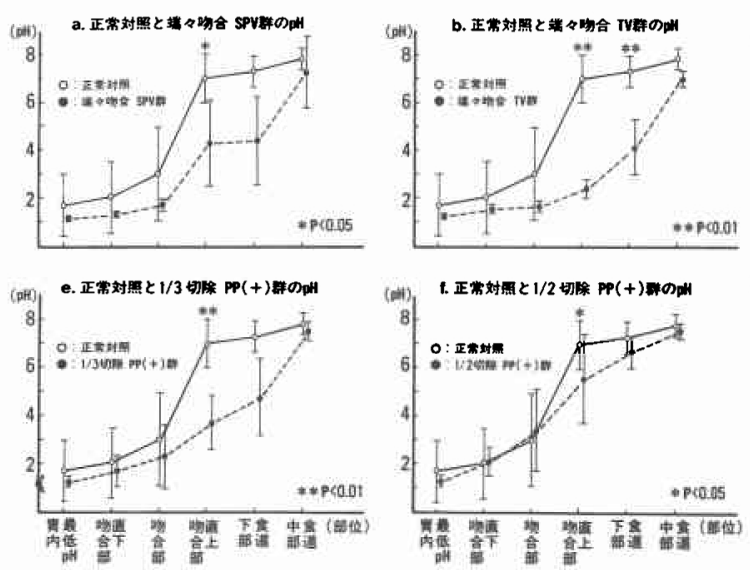
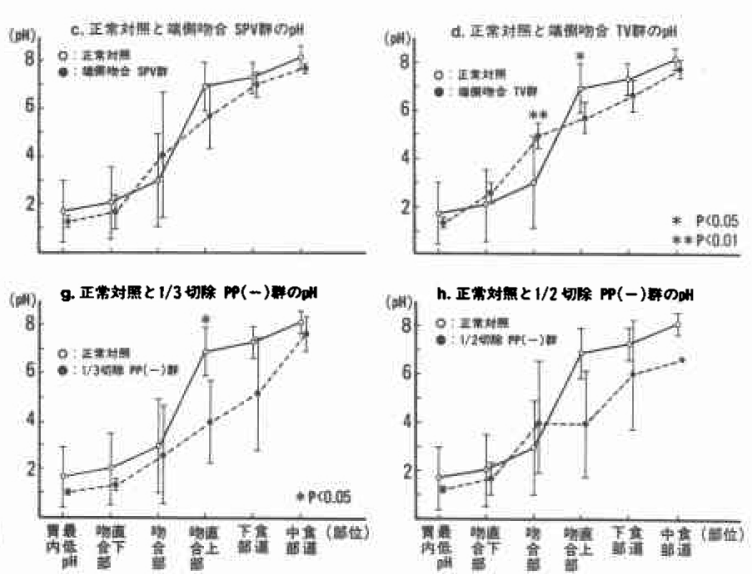
図 5 切除範囲と SPV 付加の有無, および, SPV と PP 付加の有無, より見た食道胃 内 $\mathrm{pH}$ 変化
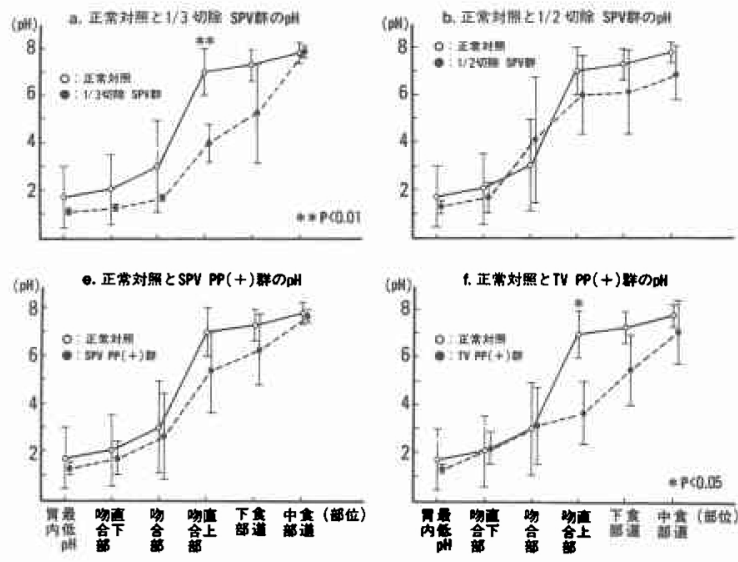

（十）で吻合部直上 $\mathrm{pH}$ の有意の低下（p<0.01および $\mathrm{p}<0.05$ ）を示した（図 $4 \mathrm{e} \cdot \mathrm{f} \cdot \mathrm{g}$ ）が $1 / 2$ 切除 $\mathrm{PP}(-)$ では有意差は見られなかった（図 $4 \mathrm{~h}$ ).

（5）切除範囲と SPV 付加の有無

$\mathrm{TV}$ 群では切除範囲に関係なく吻合部直上で $\mathrm{pH}$ の 有意の低下 $(p<0.01)$ を示した（図5c・d）。尖た，1/ 2切除では SPV 群でより対照群に近い $\mathrm{pH}$ 変化を示 した（図 5 b).

(6) SPV 付加の有無と PP 付加の有無

$\mathrm{TV} \cdot \mathrm{PP}(+)$ で吻合部直上 $\mathrm{pH}$ の有意 $(\mathrm{p}<0.05)$ の低下を認めたが（図５ｆ）, 他の群では対照群との間 に有意差は認められなかった（図 $5 \mathbf{e} \cdot \mathbf{g} \cdot \mathbf{h}$ ).

3. Ba-X 線検査による胃内容逆流

対照犬では頭部 $20^{\circ}$ 低位でも, 背卧位, 腹卧位とも胃 内容の食道内逆流は全く見られなかった。 E-E 群では 頭部 $20^{\circ}$ 低位で背卧位, 腹臥位ともに全例著明な逆流が 見られた．E-S 群では頭部 $20^{\circ}$ 低位背臥位撮影で逆流か゚ 見られたが, E-E 群に比べ逆流の程度は軽度であった。 切除範囲のちがいでは, 1/2切除群で逆流が多い傾向が 見られた。しかし SPV およびPPの付加に分けて検討 しても，各群間に著明な差は認められなかった。

4. 胃および十二指腸運動

1) 基礎的検討事項

一定量 $(20 \mathrm{gr} / \mathrm{kg})$ の Dog foodを 1 日 1 回投与し胃 十二指腸運動を連続的に記録観察したところ，1日の 胃十二指腸運動は，2 種類の pattern に大別された. 図 6 は対照犬の胃各部拉よび十二指腸に 8 個の strain gauge force transducerを縫着後 2 週目の記録であ る. 食慨投与前の空腹期には，胃各部および十二指腸
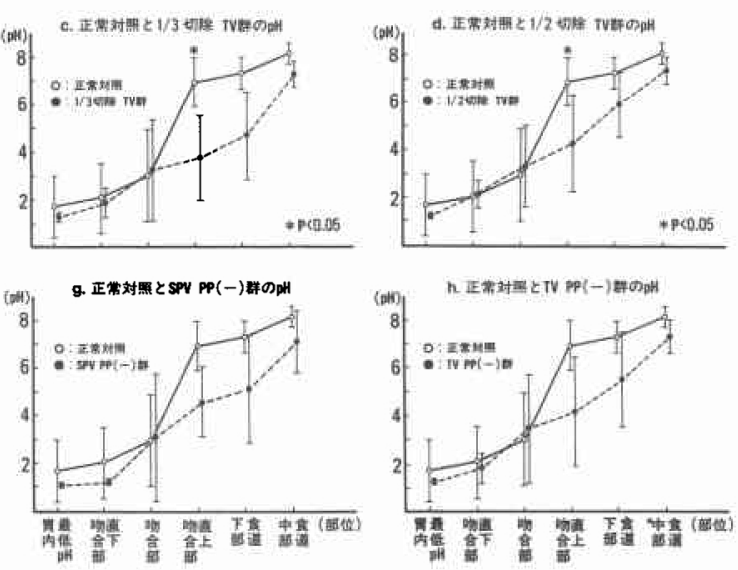

図 6 正常犬の胃運動

明瞭な DP とIPが認められる

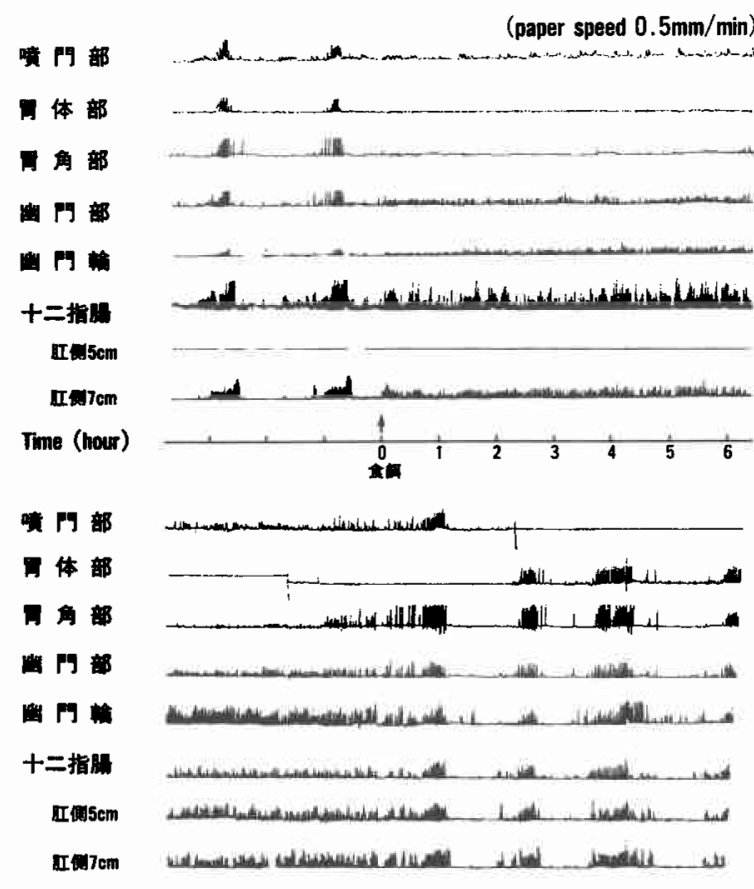

Time (hour)

にほぼ同期した強収縮の連続する強収縮期（以下 IMC) と休止期が繰返し見られる interdigestive pattern (以下 IP) が見られ (図 6 左手)，食慨を投与する と小収縮の連続する digestive pattern (以下 DP) に急 速に移行した．DP は食飼投与後11時間目ごろまで続 き，最初の IMC 様取縮を示した後 IP 乞と移行した。 
図 7 空腹期の胃十二指腸運動

a：正常犬. b：噴門側 $1 / 2$ 胃切除 SPV • PP $(-)$ 術

後. c : TV 術後（食後30時間）
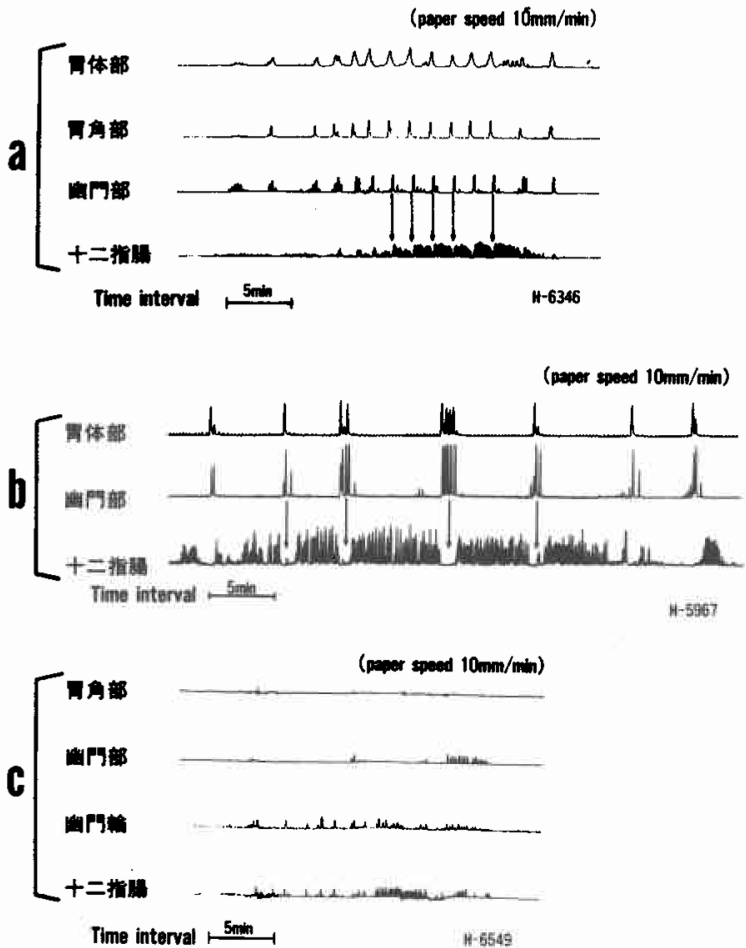

このIP は次に食餌を与えるまで続いた，DPの持続時 間は，食䬲投与量により変化し，食慨量が増加すると DP 持続時間は延長したＩP について見ると，休止期 は60～80min., IMC の持続時間は25〜30minであっ た。次に IMC を高速 $(10 \mathrm{~mm} / \mathrm{min})$ で記録し検討する
と, 胃体部に発生した収縮波は胃角部，幽門部之順次 层播していく様子が観察された（図７ａ）。十二指腸で は矢印で示されるように幽門部の強収縮に一致して収 縮は休止して扣り，逆に幽門部の休止期には頻回に強 収縮を繰返していることが観察された。

（2）SPV 後の胃十二指腸運動

SPV 後の胃十二指腸運動は対照犬にほ注類似して いた.すなわち食後の DP 和よび空腹期の IP は良く保 たれていた，DPの持続時間は，対照犬に比べ延長する 傾向が見られ，図 8 のごとく食餌投与後約17時間目頃 DPへの移行が見られた．IPについて見ると，休止期 は60min 前後であり, IMC の持続時間は20〜30 min で あった（図 8).

（3）TV 後の胃十二指腸運動

TV 後の胃十二指腸運動は著明に低下した。食慨投 与後胃体部には post receptive relaxation 様変化は見 られるが, 明瞭なDP は見られず，また食餌投与後23時 間経過後もIPの出現は見られなかった（図９）。食餌 投与後 30 時間後の運動を高速 $(10 \mathrm{mn} / \mathrm{min})$ で記録し検 討してみると，胃十二指腸の運動は著明に低下し，胃 各部扣よび胃と十二指腸間の連係した運動も全く認め られなかった（図７c）。

2）噴切術後の胃十二指腸運動

（1） $1 / 3$ 妡除 SPV 群の胃十二指腸運動を経時的に 観察すると, 食䬲投与後 6 時間目まで胃各部および十 二指腸に小収縮の連続するDP が見られ，その後11時 間目まで胃体部および胃角部にさらに小さい収縮の連 続が観察され，胃各部および十二指腸に IMC 様収縮 が起こった後, 漸次 IPへ移行した（図10），同一犬に Barium meal 投与後経時的に胃内容排出状態を観察

図 8 選択的近位迷走神経切離術 (SPV) 後の胃運動 SPV 後にはDP 扣よびIPは良く温存されている
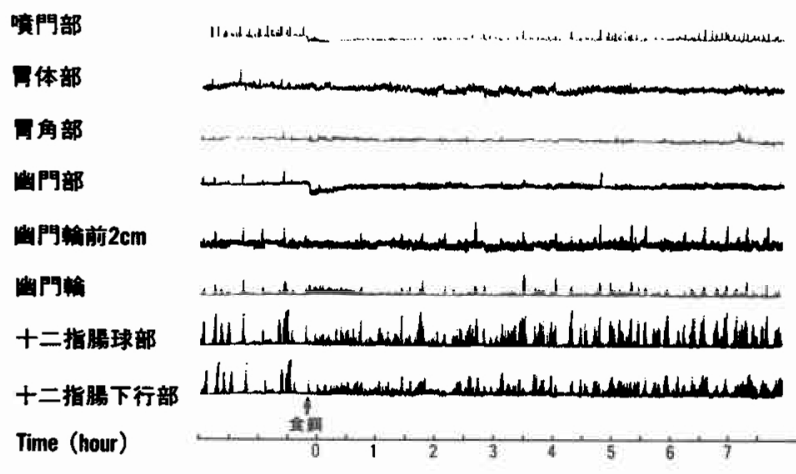

(paper speed $0.5 \mathrm{~mm} / \mathrm{min}$ )
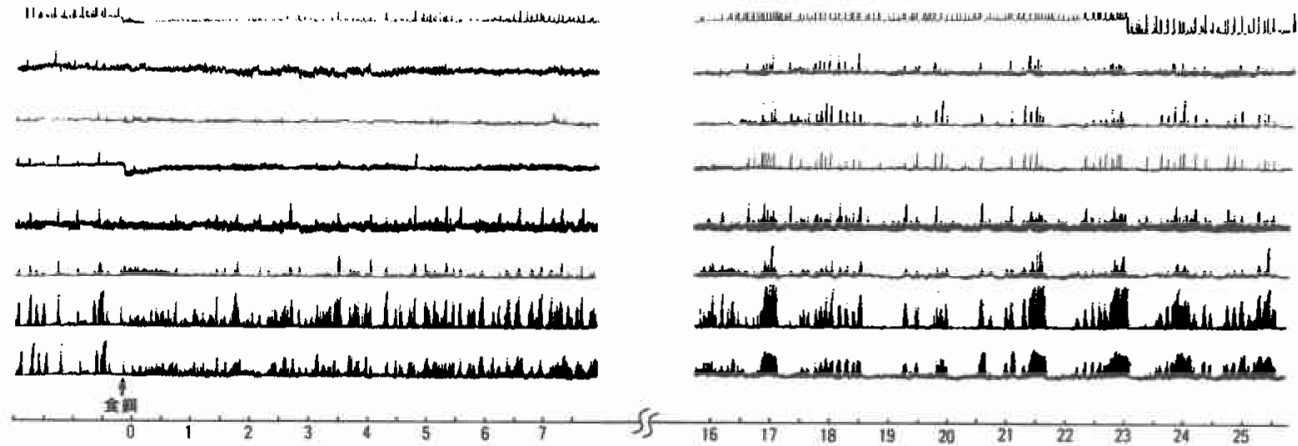
図 9 幹迷送神経切離術 (TV) 後の胃運動

TV 後胃運動は著明に低下し, DP, IP は認められない

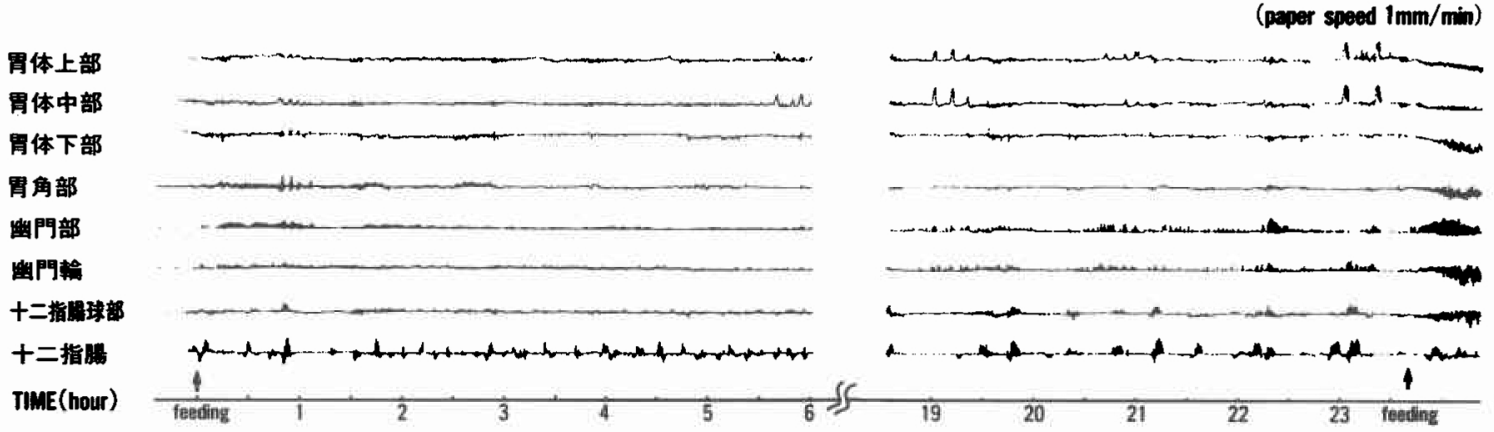

図10 噴門側 $1 / 3$ 胃切 SPV・PP (一) 術後の胃運動

DP, IP は良く温存されている。

(paper speed $1 \mathrm{~mm} / \mathrm{min}$ )

\section{胃体部}
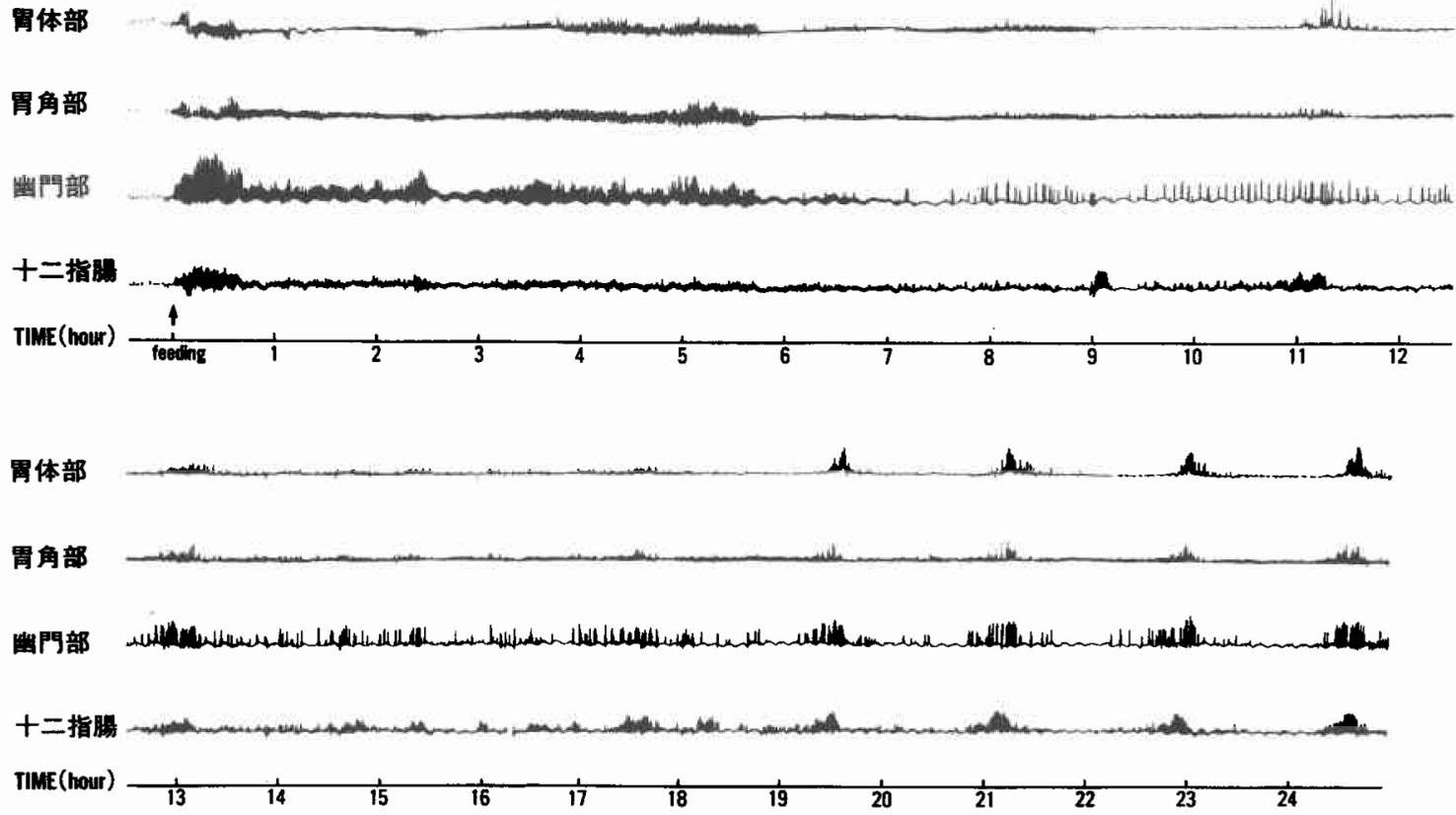

すると，6 時間後では胃に多量の Ba が残存していた。 その後徐々に胃内残存 Ba は減少し, 初回 IMCの出現 した11時間目には胃内残存 Ba は認められなかった (図11).1/3切除 SPV・PP (十) 群でも同様に DP, IP は温存され，胃と十二指腸間の連係運動的観察された。

（2） $1 / 2$ 切除 SPV 群の胃十二指腸運動

$1 / 2$ 切除 SPV 群 6 例中 4 例で，対照犬と類似した日

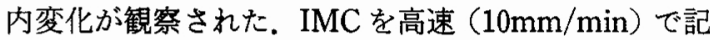
録し検討してみると，胃体部の収縮は幽門部に良く伝
播し，矢印のごとく幽門部の収縮に一致して十二指腸 収縮は休止しており，胃十二指腸間の連係保たれて いた (図 7 b). これはPP 付加の有無に無関係であっ た。しかし，1/2切除 SPV 群の 2 例では, IP が不明瞭 であった。図12は $1 / 2$ 切除 SPV・PP（一）例の胃十二 指腸運動の記録であるが，食飭投与後 DP 様収縮が見 られるが，IPへの移行は見られなかった，1/2切除 SPV 群では, このように非定型的運動を示す例も見ら れた。 
図11：噴門側1/3胃切除 SPV・PP (一) 後の胃排出

初回 IMCの出現した11時間目には胃内に残存パリューム陰影を認めない
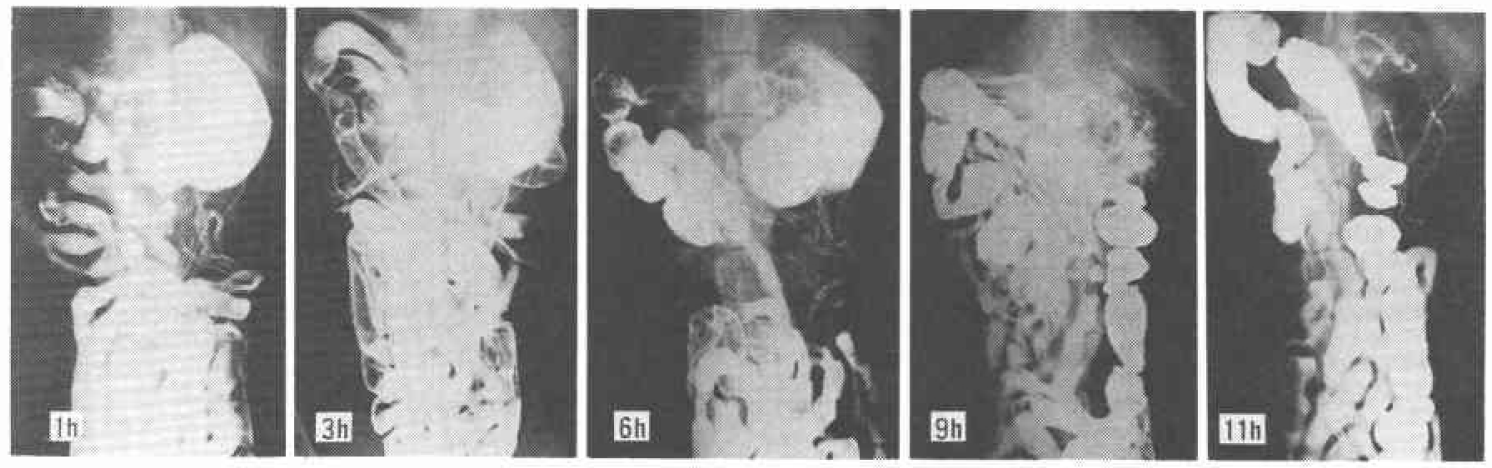

図12 噴門側 $1 / 2$ 胃切除 SPV・PP (一) 術後の胃運動

DP 様運動は見られるが IP への移行は見られない。

(paper speed $1 \mathrm{~mm} / \mathrm{min}$ )
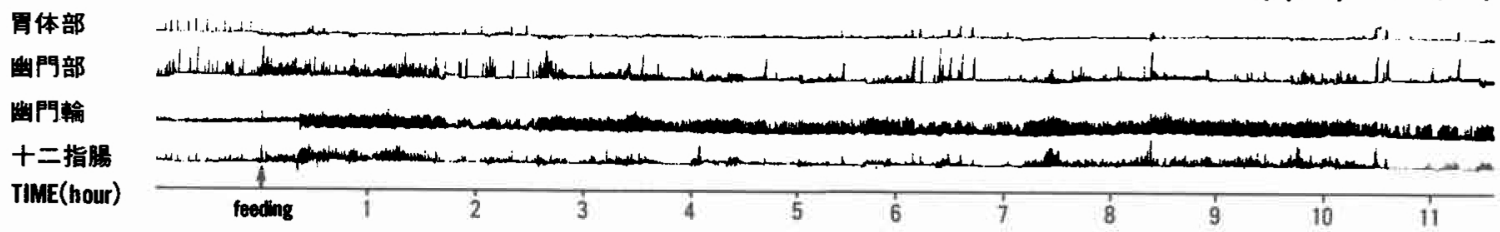

胃体部
㟧門部
十二指
十指腸

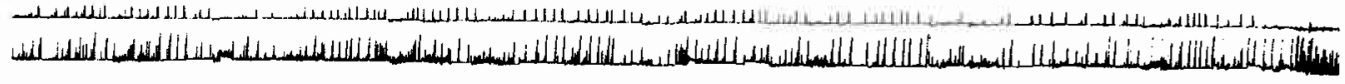

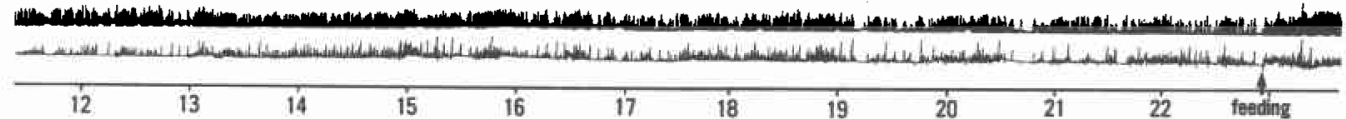

（3）噴切兼 TV 術後の贯十二指腸運動

噴切兼 TV 群では, 切除範囲和よび吻合法, PP 付加 の有無に無関係に胃の運動は低下し，胃各部执よび胃 十二指腸間の連係も全く見られなかった。

5. 食道炎の有無・程度

（1）切除範囲のちがいと食道炎

1/3切除群では E-E 群で全例食道炎が認められた が, E-S 群では 7 例に食道资は認められず, 両者間に有 意差 $(\mathrm{p}<0.01)$ が認められた。 また，1/2切除群では, PP (一) 群で全例に食道炎が認められたが, PP (十) 群で58.3\%であり有意 $(\mathrm{p}<0.05)$ に食道炎は少なかっ た. 1/3切除群では PP (十) 群と PP (一) 群の間に有 意差は見られなかった（表 1 ）.

（2）吻合法のちがいと食道炎

E-S 群では, 1/3切除群, PP (十) 群, SPV 群で E$\mathrm{E}$ 群に比べ食道炎は有意に少なかった（p<0.01, $\mathrm{p}<$
表 1 七除範囲および再建・付加術式別の食道炎の有 無

\begin{tabular}{|c|c|c|c|c|c|c|c|c|c|c|c|}
\hline \multirow{2}{*}{\multicolumn{2}{|c|}{ 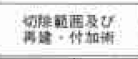 }} & \multicolumn{2}{|c|}{ 复 in $\mathrm{k}$} & \multirow{2}{*}{\multicolumn{2}{|c|}{ क }} & \multirow{2}{*}{\multicolumn{2}{|c|}{ 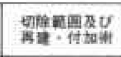 }} & \multicolumn{2}{|c|}{ t ill } & \multirow{2}{*}{$\pi$} & \multirow{2}{*}{$8 \%$} \\
\hline & & \multirow{2}{*}{$\frac{\text { (Di) }}{12}$} & \multirow{2}{*}{$\frac{4 \mathrm{~L}}{0}$} & & & & & की & $8 \mathrm{~L}$ & & \\
\hline \multirow{2}{*}{$1 / 301 \%$} & $\mathbb{E}-\mathbf{E}$ & & & \multirow{2}{*}{$\mid P(0,01$} & \multirow{4}{*}{ I MS } & \multirow{2}{*}{$p p(+)$} & $E-E$ & 11 & 1 & \multirow{2}{*}{$1 P<0.01$} & \multirow{4}{*}{$P<0.07$} \\
\hline & $E-S$ & 5 & 7 & & & & E-S & 3 & 9 & & \\
\hline \multirow{2}{*}{$1 / 24918$} & E-E & 11 & 1 & \multirow{2}{*}{ NS } & & & $E-E$ & 12 & 0 & \multirow{2}{*}{ NS: } & \\
\hline & E-S & 8 & 4 & & & & $E-S$ & 10 & 2 & & \\
\hline \multirow{2}{*}{$1 / 3$ 打降 } & $P P(+)$ & 7 & 5 & \multirow{2}{*}{ NS } & \multirow{4}{*}{ NS } & \multirow{2}{*}{ sPV } & $E-E$ & 12 & 0 & \multirow{2}{*}{$\mid P<0,02$} & \multirow{4}{*}{ HS } \\
\hline & $P P(-)$ & 10 & 2 & & & & $E-S$ & 5 & 7 & & \\
\hline \multirow{2}{*}{ 1/2 해웅 } & $P P(+)$ & 7 & 5 & \multirow{2}{*}{ IPCo.05 } & & \multirow{2}{*}{ TV } & $E-\mathbf{E}$ & 11 & 1 & \multirow{2}{*}{ HS } & \\
\hline & $P P(-)$ & 12 & 0 & & & & $E-5$ & 8 & 4 & & \\
\hline \multirow{2}{*}{ 1/3日月: } & SPV & 8 & 4 & \multirow{2}{*}{ NS } & \multirow{4}{*}{ NS } & \multirow{2}{*}{$P P(+)$} & SPV & 6 & 6 & \multirow{2}{*}{ MS } & \multirow{4}{*}{$1 \mathrm{PC0} 002$} \\
\hline & TV & 9 & 3 & & & & TV & 8 & 4 & & \\
\hline \multirow{2}{*}{$1 / 2$ an } & SPV & 9 & 3 & & & & SPV & 11 & 1 & & \\
\hline & TV & 10 & 2 & taitopent & & $m+1-1$ & TV & 11 & 1 & NS & \\
\hline
\end{tabular}

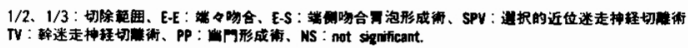


0.02). また, E-S 群の $1 / 2$ 切除群, PP (一)群, TV 群 でも E-E群に比べ食道炎が起こりにくい傾向にあっ た（表 1).

（3）PP およびSPV の有無と食道炎

$\mathrm{PP}(+)$ 群で $\mathrm{PP}(-)$ 群に比べ有意 $(\mathrm{p}<0.02)$ に 食道炎は少なく，1/2切除群で特にその傾向が強かっ た. SPV 付加の有無では，いゔれの場合にも有意差は 認められなかった。

\section{IV. 考 察}

下部食道噴門部に手術操作がおがよ゙噴切術後は，接 合部付近に存在する逆流防止機構が破壊されるため， 手術に際し何らかの逆流防止のための工夫が必要々 なってくる，噴切術後の逆流防止法としては大きく分 けて，(1)食道胃吻合口に扣ける逆流防止の工夫 ${ }^{10) \sim 12), ~}$ (2)食道内への逆流路の延長化 ${ }^{13114)}$, (3)胃内容排出促進, などが報告されてきている。しかしこれらの逆流防止 術式は，手術手技が煩雑な術式が多く普及性にとぽし いそこで著者は，イヌを用いて，噴切の切除範囲の らがい，吻合法(E-E たたE-S)のちがい，付加手術 (PP拈よびSPV)の有無などの組み合わせによる食道 内逆流現象抢よび胃運動の状態につき検討した。

接合部の内圧変化から E-E 抢よびE-Sについて検 討すると, 両吻合法ともに対照と比較し, 接合部最高 圧, 接合部昇圧帯の長さ，接合部前後の圧差の 3 者と るに低下しており，逆流のおこりやすい状態となって いる。しかし，E-E と E-Sで比較すると接合部最高圧 は E-S で有意 $(\mathrm{p}<0.01)$ に高值であり，E-S で逆流防 止に有利であることは明らかである。実際の $\mathrm{pH}$ 測定 に执いても E-Sでは下部食道 $\mathrm{pH}$ は高く, 逆流の少な いことを示している．吻合法のちがいに関して樋ロ ${ }^{11}$ は動物実験の結果から, 大津 ${ }^{15}$ は臨床例の検討から, 噴 切術後端側吻合が端々吻合に比べ食道内逆流は少く, 逆流性食道炎の発生が低いと報告している。しかし彼 らは, 端側吻合に招いても60\%に逆流性食道炎を認め, 端側吻合のみでは，逆流防止は不十分であるとし，弁 形成吻合の有用性を強調している. 著者の実験では, 食道炎は E-S に招いて $1 / 3$ 切除群, PP (十) 群, SPV 群で軽度であり，吻合法に加兄て何らかの術式を併せ 行觉ば，食道炎を予防出来る可能性があることが分っ た。

田北 ${ }^{16)}$ は，X 線映画撮影法にて臨床例を検討し，噴 切術の切除範囲が大きい場合は, 残胃内容の著明な食 道内逆流を認め，小範囲切除で残胃容量が大きい場合 は，逆蠕動は存在するるのの食道内への逆流は少な
かったと報告している。小野ら 影法を用い, 残胃運動を追跡した結果, 胃切除量 $1 / 3 て ゙$ は残胃の形態は非切除正常胃に近く, 残胃の運動によ り胃内容は十二指腸に排出されるが，切除量が $1 / 2,2 /$ 3と大きくなるにつれ胃内容排出が障害されることを

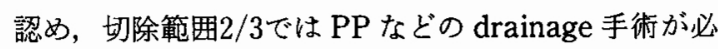
要であると報告している，切除範囲について著者の実 験で, 内圧測定に打いては, $1 / 3$ 切除群と $1 / 2$ 切除群に は差が見られなかった. $\mathrm{pH}$ 変化で見てみると,吻合法 のちがいに関しては，切除範囲に無関係に E-Eに比べ E-S で酸の逆流は少い傾向にあった. しかし, PP 付加 の有無, および SPV 付加の有無を加味して検討する と, $1 / 3$ 切除 PP (-) 群や1/3切除 TV 群に比べ, $1 / 2$ 切除 $P P(+)$ 群や $1 / 2$ 切除 SPV 群に执いて, 上り正常 犬に近い $\mathrm{pH}$ 変化を示していた. 以上のように, 切除範 囲のちがいについて見ると，切除範囲のちがいは単に 残胃貯蔵能の差だけでなく，むしろ残胃の運動機能に 強く関連づけられるものと思われた。

著者の実験で SPV 群の運動を見ると，1/3切除例で は全例正常犬と類似した日内変動を示し, 相沢ら ${ }^{18)}$ が 無処置正常犬で指摘した. IP と DP の両 pattern が噴 切術後にも温存されていることを確認した。しかし， $1 / 2$ 切除 SPV 群では 6 例中 4 例で残胃運動は良く保 たれていたが，2例においては，非定型的日内変化が 見られこのような例では，胃排出も荤延していた。 棋 $^{199}$, 白鳥ら ${ }^{20)}$ は, 噴門側胃の切除範囲の大きさによっ て残胃の運動が異なることに注目し, 噴切術後は, 迷 走神経の切離による残胃運動の変調というょりむし ろ, 胃壁の切離そのものに残胃運動機能の変化の原因 を求めた。すなわち, 噴切による胃運動の pacemaker の脱落を強調し, 噴切術後の胃内容の排出遅延の発生 機序として, 術後の（特に幽門洞の）逆螦動運動を挙 げ, 迷走神経温存の有無に関係なく, PP が必要である と述べている.さらに, 筋電図学的検討から, PP 付加 により逆蠕動放電の出現率は減少し, 肉眼的にも逆蠕 動運動は減弱したと報告している.しかし古根川211は, イヌを用いた慢性実験により，術直後には幽門部に異 常放電を認めたが，一定期間を置いた慢性期には，楨 ら ${ }^{19)}$ 云う逆蠕動発生に伴う幽門部の異常興奮を認め なかったと報告し，さらに，幽門部浆膜笳層切離術後 の逆放電発生頻度は, 術前と比較し有意の差を認めず, PP そのものは, 胃の活動電位には大きな影響を与兄 ないと述べている. 迷走神経切離後, 胃運動は著明に 低下するとの報告 ${ }^{22233}$ 恀く，著者の実験結果でる， 
$T V$ 後拉よび噴切 TV 後には，運動の著明な低下を認 めた. しかし, SPV 後には胃の運動低下は軽度であり, 噴切 SPV 後ではPPを付加しても残胃の運動性に相 異は見られなかった。したがって，噴切術後には，PP は常に必要とされるものではなく，他の付加手術を考 慮に入れ, また, PP 付加に上る十二指腸液の逆流など の demeritにも注意を向け, 慎重に PP 付加の適応を 考えるべきもの思われた．著者の実験に颃いては, $1 / 2$ 切除群で $\mathrm{PP}(+)$ 群と $\mathrm{PP}(-)$ 群の間に以下の点 で差が見られた。すなわち, 食道胃内 $\mathrm{pH}$ 変化を食道胃 吻合法のちがいと PP 付加の有無から検討すると，E$\mathrm{E}$ 群では PP $(+)$ 群で, より正常犬に近い $\mathrm{pH}$ 変化を 示し, 逆流の少ないことを示している。これは PP 付加 により胃排出が早期に起こることを示している。しか し, E-S 群では PP (十) 群と PP (一) 群に有意差は なかった。また切除範囲が大きい場合には, 吻合部直 上 $\mathrm{pH}$ は $\mathrm{PP}(+)$ 群で高く, 酸の逆流は少なかった。 しかし切除範囲が大きく, かっ PP (十)群では十二指 腸液の胃内逆流を認める例が多く，それに伴う十二指 腸液の食道内逆流子考慮に入れる必要があると思われ た. 次に食道炎の有無で検討してみると，1/2切除群で はPP $(-)$ 群は $\mathrm{PP}(+)$ 群より有意 $(\mathrm{p}<0.05)$ に食 道炎発生頻度が高く, 切除範囲が大きい場合には PP 付加が食道炎予防に有利であると思われた。

著者は, 対照犬の胃十二指腸運動を高速 (10mm/ $\mathrm{min}$ )で観察記録し, 空腹期に括ける胃十二指腸の運動 を検討したところ，IMCにおいて胃幽門部と十二指腸 球部の間の非常に密接な連係運動を観察した。すなわ ち, 幽門洞の強收縮時に十二指腸は拡張状態で休止し, あたか子幽門洞より排出された内容を受け入れるがご とき運動を行った。 また逆に，幽門洞に收縮を認めな い時には，十二指腸は頻回に強収縮を繰り返し，あた かも胃内への十二指腸内容の逆流を防止寸るかのごと くであった。この事実は伊藤らも報告して抢り，いわ ゆる interdigestive house keeperとしての役割を忠 実に果しているすのと思われた。ささらに著者は，噴切 術後の胃運動の観察においても, SPV 群で対照犬と用 様の胃十二指腸連係運動を確認した。またこの連係は, PPの有無に影響されないことも認めて括り，SPVの 胃運動就よび胃排出に対する有用性が強く示唆され た.

\section{V. 結 語}

噴切衍後の食道胃逆流現象および胃排出状態を, 食 道胃内 $\mathrm{pH} \cdot$ 内圧, 残胃運動, 食道炎の有無・程度を指
標として, 食道胃吻合法, 胃切除範用, PP あるいは SPV 付加の有無により検討し, 以下の結果を得た。

1. E-S 群の食道胃接合部最高圧は, $4.2 \pm 0.7 \mathrm{cmH}_{2}$ Oで, E-E 群に比べ有意に高値であった。切除範囲のち がい,および付加手術の有無では有意差は見られな かった.

2. 食道内 $\mathrm{pH}$ は, E-S 群で $\mathrm{E}-\mathrm{E}$ 群に比べ高値であ り, 1/3切除 SPV 群, $1 / 2$ 切除 SPV 群で対照犬に類似 した $\mathrm{pH}$ 変化を見せた. PP 付加の有無では, 有意差は 認められなかった。

3. 麻醉下X線検查では, E-S 群, $1 / 3$ 切除群で逆流は 軽度であった. 意識下胃排出検査では, SPV 群で胃排 出は良好であり, TV 群では胃排出の著明な達延を認 めた。

4. 胃運動を観察すると, 1/3切除 SPV 群の全例, 1/ 2 切除 SPV 群の $67 \%$ に匡ほ正常の日内変化が認めら れ,これは PP 付加の有無に無関係であった。胃十二指 腸間の連係運動もSPV 群では良く保たれていた.TV 群および $1 / 2$ 切除 SPV 群の $33 \% て ゙$ 胃運動は著明に抑 制され，胃十二指腸間の連係も消失していた。

5. 食道炎の程度は, E-S 群で E-E 群に比べ軽度で あった、 1/3切除群, $1 / 2$ 切除群ともにPP (+)群で食 道炎は軽度であったが, SPV を加味すると, 1/3切除群 では差が認められず，1/2切除群では PP (十) 群で軽 度であった。

6. 以上の成績から, 噴切術後の吻合法は, 食道胃前 壁端側吻合胃泡形成術がすぐれており，さらに $1 / 3$ 切除 の場合は, SPVを付加すれば PP 付加は必ずしも必要 ではない. 1/2切除の場合は, SPV 付加の有無に関係な くPPを付加するのが適当であることが分かった。

本論文の要旨は, 第26,27回日本平滑筋学会総会 (1984, 1985), 第70回日本消化器病学会総会(1984), 第26回日本消 化器外科学会総会 (1985) において発表した.

稿を終るにあたり，御指導，御校閲いただいた恩師城所 仂教授に深甚なる謝意を表します。また，終始御指導·御鞭 撻いただいた渡部洋三講師, 御指導·御協力賜った群馬大学 伊藤 漸教授,ならびに御協力下さった研究室各位に深勆 致します。

\section{文 献}

1) Mikulicz J: Beiträge zur technik der operation des magen-carcinoms. V Langenbeck's Archiv Bd 19:252-260, 1898

2) Voelcker $H$ : Üeber exstirapation der cardia wegen carcinoms. Dtsh Zschr $22: 126-129$, 1908 
3）久留勝: 噴門部潰瘍の治療について。治療 $34: 529-533,1952$

4）長尾房大, 青木照明：高位胃潰痬に対する手術々 式. 外科診療 $14: 157-163,1972$

5) Watkins DH, Prevedel A, Harper FR: A method of preventing petric esophagitis follow. ing esophago-gastrostomy. J Thorac Surg 28 : $367-382,1954$

6）籏福哲彦, 樋口隆広, 大津幸世注加：弁形成食道・ 胃吻合法の手術手技. 手術 $30: 891-900,1976$

7) Sirak HD, Clatworthy HW, Elliott DW et al : An evaluation of jejunal and colic transplantations in experimental esophagitis. Surgery 36 : 399-411, 1954

8) Code CF : An atlas of esophageal motility in health and disease. Illinois Charles C. Thomas Publisher, 1958

9）伊藤 漸： extraluminal strain gauge force transducer $の$ 作成之慢性植込. 日平滑筋会誌 $13: 33-43,1976$

10）桑島輝夫, 古根川龍司, 古味信彦ほか: 弁形成食 道・胃吻合術式の検討. 日臨外医会誌 $41: 846$ $-851,1980$

11）桶口隆広：近側胃切除術に打ける各種食道・胃吻 合法と逆流に関する研究. 日外会誌 $78: 132$ $-147,1977$

12）松代 隆, 針生常郎, 長嶋英幸深：逆流防止弁形 成食道胃吻合術. 日消外会誌 $16: 2053-2059$, 1983

13) Merendino KL, Dillard DH : The concept of sphincter substitution by an interposed jejunal segment for anatomic and physiologic abnormalities at the esophagogastric junction. Ann Surg $142: 486-509,1955$

14) Moylan JP, Bell JW, Cantrell JR et al: The jejunal interposition operation. A follow-up on seventeen patients followed 10 to 17 years. Ann Surg 172:205-211, 1970

15）大津幸世：術式別にみた逆流性食道资の発生頻度 と病態に関する臨床的研究. 日消外会誌 14 ： 1525-1533, 1981

16）田北周平, 西島早見, 藤岡興人ほか：食道下端に於 ける吻合口機能の研究. 臨と研 $36: 772-779$, 1959

17）小野慶一：噴門側胃切除に伴ら機能障害々対策. 日消外会誌 $2: 196-205,1970$

18）相沢 勇, 竹内真人, 伊藤 漸ほか：イヌにおける 胃運動の日内変化. 日平滑筋会誌 $13: 1-8,1977$

19）楨 哲夫, 白鳥常男, 山口 耑ほか: 近側贯切除術 式の検討. 手術 $20: 45-51,1966$

20）白鳥常男：噴門側胃切除に伴 弓機能障害と対策. 日消外会誌 $2: 196-205,1970$

21）古根川龍司：イヌ胃に招ける近側胃切除術後の筋 電図学的研究. 日平滑筋会誌 $14: 29-41,1978$

22）桑島輝夫：各種迷切のイヌ胃運動機能に及ぼす影 響についての研究. 日平滑筋会誌 $13: 55-67$, 1977

23）白鳥常男 : 運動機能からみた胃の手術. 日消外会 誌 $17: 507-516,1984$ 